\title{
Lipid and fatty acid profiles of Castanea sativa Mill. Chestnuts of 17 native Portuguese cultivars
}

\author{
Olga Pires Borges ${ }^{\mathrm{a}}$, José Soeiro Carvalho ${ }^{\mathrm{a}}$, Paula Reis Correia ${ }^{\mathrm{b}}$, Ana Paula Silva ${ }^{\mathrm{c}, *}$ \\ ${ }^{a}$ Direção Regional de Agricultura de Trás-os-Montes, Quinta do Valongo, Carvalhais, 5370-087 Mirandela, Portugal \\ ${ }^{\mathrm{b}}$ Escola Superior Agrária de Viseu, Quinta da Alagoa, Estrada de Nelas, Ranhados, 3500-606 Viseu, Portugal \\ ${ }^{\mathrm{c}}$ Universidade de Trás-os-Montes e Alto Douro, CECEA, Quinta dos Prados, 5000-911 Vila Real, Portugal
}

Received 16 November 2005; received in revised form 5 July 2006; accepted 5 July 2006

\begin{abstract}
In recent years, chestnuts have increasingly become important in human nutrition because of their nutrient contents and potential beneficial health effects. In Portugal, Trás-os-Montes e Alto Douro is the most important region for chestnut production, generating $85 \%$ of the total national output. In 1994, three chestnut protected designation of origin (PDO) areas were created: Terra Fria, Soutos da Lapa, and Padrela within the jurisdiction area of the Regional Agricultural Services of Trás-os-Montes Region. Seventeen cultivars were selected from these PDO to evaluate crude fat content and fatty acid (FA) composition over a period of 2 years. Total fat extraction was performed according to AOAC methodology, using a Soxhlet apparatus for $16 \mathrm{~h}$. Petroleum ether was used for extraction and FAs were identified and quantified by gas chromatography. The cultivars studied confirm that chestnuts have low crude fat content, low saturated fatty acids (SFA) $(17 \%)$ and high unsaturated fatty acids (USFA) $(83 \%)$. The major FAs are linoleic, oleic and palmitic; these accounted for more than $85 \%$ of the total FA content. From the results two potentially health-beneficial cultivars were identified: cv. Lada, with high linoleic acid content, and cv. Aveleira, with higher USFA content. With respect to FA profiles of chestnuts from the three PDO regions, Padrela chestnuts consistently contained the highest level of linoleic acid. The variation detected among cultivars and PDO areas may reflect differences in genotype and are influenced by environmental and growing conditions. The Longal chestnuts, the only traditional cv. growing on two different PDO areas, had better nutritional qualities in PDO Terra Fria, which confirm that the ecological conditions where chestnut orchards are established influences nut quality.
\end{abstract}

(C) 2006 Elsevier Inc. All rights reserved.

Keywords: Chestnut; Castanea sativa Mill.; Gas chromatograph; Protected designation of origin (PDO); Genotype; Crude fat; Fatty acid composition

\section{Introduction}

The sweet chestnut tree (Castanea sativa L.) produces chestnuts, which are an ancient tree crop in northern Portugal of great social and economic importance. They were a basic foodstuff for many families until potatoes and cereals became available. The Trás-os-Montes e Alto Douro region is one of the most favorable in terms of climatic, edaphic and ecological conditions. Nowadays, this region stands out as the most important chestnutproducing area of the country, generating $85 \%$ of the total national chestnut output, and it is one of the few regions

\footnotetext{
*Corresponding author. Tel.: + 351259350450 ; fax: + 351259350327.

E-mail address: asilva@utad.pt (A. Paula Silva).
}

with a largely positive trade balance, which was about 9 million euros in 2002 and continues to show annual improvements (GPPAA, 2003).

In Trás-os-Montes e Alto Douro there are three protected designations of origin (PDO) areas for chestnuts: Terra Fria, Padrela and Soutos da Lapa. In each PDO, with different ecologies and geographical parameters, many well-adapted native cultivars are cultivated.

In recent years, chestnuts have become more important in human health because of their nutritional qualities and potential beneficial health effects. Chestnut fruits could be used as human and animal foods as extensively as potato and most of the tubers (Ferreira-Cardoso et al., 1999). Consumers have been showing an increased interest in food composition particularly with respect to fatty acid (FA) 
contents. Essential FAs are important because of their role in diverse physiological processes affecting normal health and chronic diseases, such as the regulation of plasma lipid levels, cardiovascular and immune function, insulin action and neuronal development and visual function (Benatti et al., 2004). The consumption of omega-3 FAs can slow the growth of cancerous cells, increase the efficacy of chemotherapy and reduce the side effects of the chemotherapy for cancer (Hardman, 2002). In addition chestnuts are currently used in pediatrics for treatment of gastroenteritis and as a gluten-free diet in cases of celiac disease (Pazianas et al., 2005). Chestnuts are a good source of essential FAs (Desmaison and Adrian, 1986; Senter et al., 1994; Ferreira-Cardoso et al., 1999; Künsch et al., 1999; Mello et al., 2001).

Several studies in other crops showed important correlations between FA composition and environmental conditions. Significant differences among genotypes and cultivation areas were found in the proportions of palmitic, palmitoleic and stearic FAs for almond kernels in California production regions (Abdallah et al., 1998). A strong influence of environmental and harvest factors on the synthesis of triglycerides was found in hazelnuts, namely those with at least one linoleic acid moiety in their structure (trilinolein, oleo-diolein, dilinolein-palmitin, dioleo-linolein and palmito-oleo-linolein) (Parcerisa et al., 1994). Myristic, palmitoleic, stearic and oleic acids were negatively correlated with latitude of non-glutinous rice cultivars in Japan (Kitta et al., 2005). Ferreira-Cardoso et al. (1999) suggest that the differences found in FA composition among cultivars could be influenced by environmental and growth conditions, but more work needs to be done. Gomes et al. (1997) also detected a relationship between the protein content of chestnuts and the type of soil in which the trees had been grown.

Data on crude fat and FA composition from traditional economically important Portuguese cultivars is still limited. The purpose of this study was to evaluate the variation in crude fat and FA composition among 17 cultivars of sweet chestnut fruits, which grow in the three PDO from the Trás-os-Montes and Alto Douro region.

\section{Materials and methods}

Crude fat and FA profiles were determined for 17 sweet chestnut cultivars in two crop years (2001 and 2002). The selection of the cultivars was made within the three protected designation of origin (PDO) areas for chestnut tree production in the Trás-os-Montes e Alto Douro region: Terra Fria, Padrela and Soutos da Lapa. Each PDO area has specific ecological conditions (Table 1 and Fig. 1). From each PDO were selected a representative sample, consisting of three trees from the most common traditional cultivars: Redonda, Aveleira, Rebordâ, Longal, Trigueira, Boaventura, Lamela and Zeive from Terra Fria; Judia, Lada, and Cota from Padrela; Demanda, Martaínha, Ferreirinha, Cancela, Carreiró, Longal and Riscada from Soutos da Lapa. Mature chestnuts were harvested and three replications of $1 \mathrm{~kg}$ were randomly collected for each genotype.

Table 1

Portuguese chestnuts: geographic and soil characterization of protected designation of origin (PDO)

\begin{tabular}{|c|c|c|c|c|}
\hline PDO & Altitude (m) & Latitude & Longitude & Soil \\
\hline Terra Fria & $650-900$ & $41^{\circ} 40^{\prime}-41^{\circ} 55^{\prime} \mathrm{N}$ & $6^{\circ} 50^{\prime}-7^{\circ} 10^{\prime} \mathrm{W}$ & Distric cambisols from schists \\
\hline Soutos da Lapa & $700-800$ & $40^{\circ} 59^{\prime}-41^{\circ} 05^{\prime} \mathrm{N}$ & $7^{\circ} 25^{\prime}-7^{\circ} 50^{\prime} \mathrm{W}$ & Distric cambisols from granites \\
\hline
\end{tabular}

Source: Soil map region and correspondence to the world reference base for soil resources (FAO, 1998).

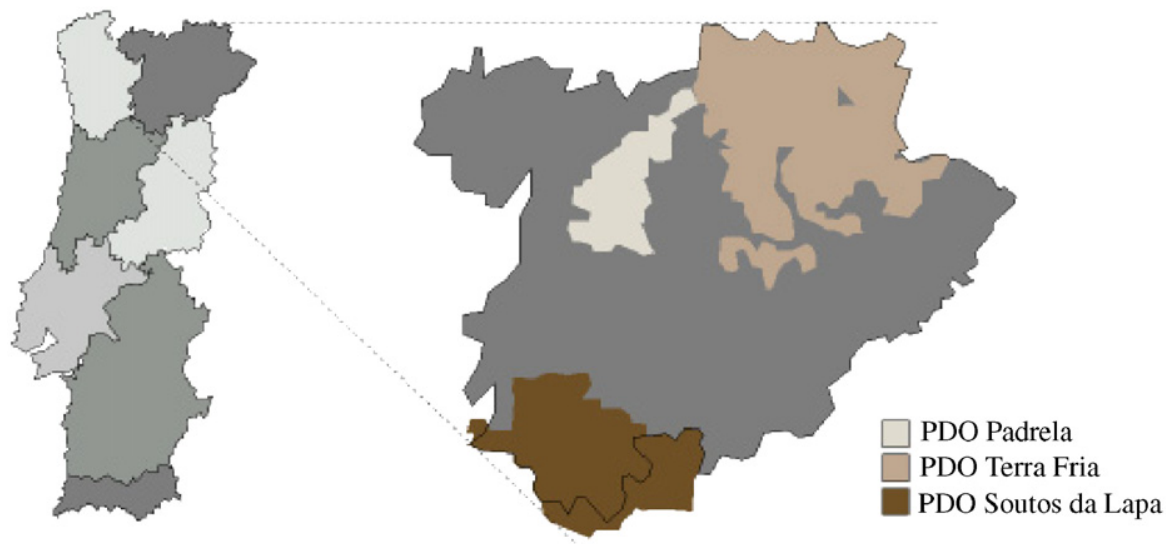

Fig. 1. Chestnut growing areas. 


\subsection{Sample preparation}

Samples were stored for 1 week in a refrigerator $\left(2{ }^{\circ} \mathrm{C}\right)$ until analyses were performed. Nut samples were predehydrated at $40{ }^{\circ} \mathrm{C}$ in a model FD 115 BINDER ventilated drying chamber for $24 \mathrm{~h}$. After drying they were peeled and the nuts rapidly cut into small pieces, in order to promote milling operations. They were further dried at $42{ }^{\circ} \mathrm{C}$ under the same conditions for $48 \mathrm{~h}$, and after drying they were milled in a model SK 100 Cross Beater RETSCH mill to a uniformly fine powder.

\subsection{Determination of total fat and FA composition}

Total fat extraction was performed according to the published AOAC (2000) methods, using a Soxhlet apparatus for $16 \mathrm{~h}$ with petroleum ether as the extraction solvent. The solvent was removed by rotary evaporation and the residue was dried for $1 \mathrm{~h}$ at $105^{\circ} \mathrm{C}$.

FA profiles were determined according the EU Regulation 2568/91 (European Union Commission, 1991) method, i.e., conversion of the free FAs released to their methyl esters (FAME) following the method of Hartman and Lago (1973). The sample preparation for injection was carried out as follow: $1 \mathrm{~g}$ of total lipids, $10 \mathrm{~mL}$ of $n$ heptane, p.a. and $0.5 \mathrm{~mL}$ of methanol solution of $\mathrm{KOH} 2 \mathrm{~N}$. This mixture was shaken and centrifuged. After derivatization a $0.45 \mu \mathrm{L}$ sample of each FAME preparation was injected into the gas chromatograph (GC). All samples were run in duplicate. The chromatography separation was performed using a Perkin-Elmer Auto-system GC equipped with a flame ionization detector, with a capillary column, SUPELCO sptm-2380, $60 \mathrm{~m}$ length, $0.25 \mathrm{~mm}$ i.d. and $0.20 \mu \mathrm{m}$ film thickness. The gas chromatography conditions: oven temperature program $-175^{\circ} \mathrm{C}$ for $25 \mathrm{~min}$ and $220^{\circ} \mathrm{C}$ for $10 \mathrm{~min}$ at a rate of $5^{\circ} \mathrm{C} / \mathrm{min}$. The injector temperature was $240^{\circ} \mathrm{C}$ and the detector temperature was $250{ }^{\circ} \mathrm{C}$. The head pressure of the carrier gas helium was maintained at $20 \mathrm{psi}$; the column flow rate was $5 \mathrm{~mL} / \mathrm{min}$. Identification and quantification of the detected FAME was carried out against external standards after adjustment through regression lines. The FA methyl esters were identified by a comparison of retention times to the FAME standards (Reg. CEE 1989/08-10). The results are expressed in relative percentage for each FA, calculated by internal normalization of the chromatographic peak area.

The FAs composition for each cultivar was examined in terms of saturated acids: myristic acid (C14:0), pentadecanoic (C15:0), palmitic (C16:0), margaric (C17:0), stearic (C18:0), arachidic (C20:0), behenic (C22:0) and lignoceric (C24:0) and unsaturated acids: palmitoleic (C16:1), margaroleic $(\mathrm{C} 17: 1)$, oleic $(\mathrm{C} 18: 1)$, linoleic $(\mathrm{C} 18: 2)$, linolenic (C18:3), and gadoleic (C20:1).

FA composition was expressed as the percentage of total FA. Values presented in the tables are the average values of three individual samples, $n=3$, each sample analyzed in triplicate.

\subsection{Statistical analysis}

The analyses of data were performed as analysis of variance using the Super ANOVA software (1.1, Abacus Concepts Inc., 1991). Mean separations were made using Fisher's Protected LSD Test $(P=0.05)$, designed to allow all possible linear combination of group means to be tested.

\section{Results and discussion}

The results of the total crude fat content of 17 chestnut cultivars are presented in Table 2 . The crude fat content was significantly affected by cultivar and crop year but did not show significant differences among PDO areas. Crude fat content was higher in $2002(2.52 \%)$ than in 2001

Table 2

Crude fat of 17 chestnuts cultivars from the three PDO areas from 2 separate years

\begin{tabular}{llll}
\hline Cultivar & PDO & Year & Crude fat $(\% \mathrm{DM})$ \\
\hline Aveleira & TF & 2001 & $2.57 \pm 0.06 \mathrm{f}$ \\
Boaventura & TF & 2001 & $2.40 \pm 0.10 \mathrm{e}$ \\
Lamela & TF & 2001 & $3.13 \pm 0.06 \mathrm{I}$ \\
Longal & TF & 2001 & $2.53 \pm 0.06 \mathrm{ef}$ \\
Rebordâ & TF & 2001 & $1.73 \pm 0.06 \mathrm{a}$ \\
Redonda & TF & 2001 & $2.73 \pm 0.06 \mathrm{gh}$ \\
Trigueira & TF & 2001 & $2.60 \pm 0.00 \mathrm{fg}$ \\
Zeive & TF & 2001 & $2.73 \pm 0.06 \mathrm{gh}$ \\
Cancela & SL & 2001 & $2.77 \pm 0.15 \mathrm{~h}$ \\
Carreiró & SL & 2001 & $2.03 \pm 0.15 \mathrm{c}$ \\
Demanda & SL & 2001 & $3.10 \pm 0.10 \mathrm{I}$ \\
Ferreirinha & SL & 2001 & $2.77 \pm 0.15 \mathrm{~h}$ \\
Longal & SL & 2001 & $1.97 \pm 0.06 \mathrm{bc}$ \\
Martaínha & SL & 2001 & $2.50 \pm 0.10 \mathrm{ef}$ \\
Riscada & SL & 2001 & $2.20 \pm 0.17 \mathrm{~b}$ \\
Cota & P & 2001 & $1.83 \pm 0.06 \mathrm{ab}$ \\
Judia & P & 2001 & $2.63 \pm 0.06 \mathrm{fgh}$ \\
Lada & P & 2001 & $1.77 \pm 0.06 \mathrm{a}$ \\
Aveleira & TF & 2002 & $3.50 \pm 0.27 \mathrm{k}$ \\
Boaventura & TF & 2002 & $2.57 \pm 0.12 \mathrm{fg}$ \\
Lamela & TF & 2002 & $3.37 \pm 0.06 \mathrm{kl}$ \\
Longal & TF & 2002 & $2.43 \pm 0.12 \mathrm{ef}$ \\
Rebordâ & TF & 2002 & $2.13 \pm 0.06 \mathrm{~cd}$ \\
Redonda & TF & 2002 & $2.40 \pm 0.00 \mathrm{def}$ \\
Trigueira & TF & 2002 & $3.07 \pm 0.06 \mathrm{ij}$ \\
Zeive & TF & 2002 & $2.73 \pm 0.06 \mathrm{gh}$ \\
Cancela & SL & 2002 & $2.80 \pm 0.10 \mathrm{ghi}$ \\
Carreiró & SL & 2002 & $2.10 \pm 0.36 \mathrm{bc}$ \\
Demanda & SL & 2002 & $3.13 \pm 0.06 \mathrm{j}$ \\
Ferreirinha & SL & 2002 & $2.87 \pm 0.06 \mathrm{hij}$ \\
Longal & SL & 2002 & $2.20 \pm 0.00 \mathrm{cde}$ \\
Martaínha & SL & 2002 & $2.60 \pm 0.17 \mathrm{fgh}$ \\
Riscada & SL & 2002 & $2.20 \pm 0.20 \mathrm{cde}$ \\
Cota & P & 2002 & $1.83 \pm 0.15 \mathrm{ab}$ \\
Judia & P & 2002 & $2.57 \pm 0.40 \mathrm{fg}$ \\
Lada & P & 2002 & $1.67 \pm 0.06 \mathrm{a}$ \\
P>0.001 & $P>05$ & $P>0.01$ & \\
\hline iiferent & & \\
\hline
\end{tabular}

Different letters within one column denote statistically significant differences $(P<0.05)$ by ANOVA and Fisher's LSD test.

Values are average of three individual samples each analysed in triplicate \pm standard deviation. 
$(2.40 \%$ ), with ranges from $1.67 \%$ for cv. Lada (PDO Padrela) in 2002 to $3.50 \%$ for cv. Aveleira (PDO Terra Fria) in the same year. These results are higher than the values reported by Ferreira-Cardoso (2002) with an average of $1.3 \%$ but lower than the values of $3.55 \%$ reported by Desmaison and Adrian (1986) and 3.6\% reported by McCarthy and Meredith (1988) for European chestnuts. These authors also presented data for other chestnut sources with crude fat values of $2.34 \%$ for American chestnuts and $1.98 \%$ for Chinese chestnuts. Üstün et al. (1999), studying 55 different types of chestnuts grown in Turkey, reported values between $0.66 \%$ and $3.08 \%$ for crude fat content. Our results confirm that chestnuts have low crude fat content compared with almonds, with values of between $36 \%$ and $53 \%$ (Abdallah et al., 1998), and hazelnuts, with values of between $46.7 \%$ and $76.8 \%$ (Parcerisa et al., 1993). Some of these differences may reflect the influence of environmental conditions and orchard management techniques.

The analysis of variance for the individual FAs (Table 3) showed significant differences for cultivar, PDO, year and the interaction of cultivar $\times$ year for the majority of samples. The source of variation "year" did not significantly affect the content of pentadecanoic, palmitic, margaric, stearic or lignoceric acids. The variation in pentadecanoic and lignoceric acids was independent of the PDO area. The content of total FA of all the cultivars studied from the three PDO areas in the 2 years is shown in Table 4. The cv. Boaventura showed the lowest value $(97.25 \mathrm{~g} / 100 \mathrm{~g})$, while cv. Zeive $(99.87 \mathrm{~g} / 100 \mathrm{~g})$ had the

Table 3

Summary of analysis of variance for fatty acid composition for year, cultivar, PDO and interaction year $\times$ cultivar

\begin{tabular}{|c|c|c|c|c|}
\hline & Cultivar & PDO & Year & Cultivar $\times$ year \\
\hline C14:0 & $* * *$ & $* *$ & $* *$ & $* * *$ \\
\hline $\mathrm{C} 15: 0$ & $* * *$ & Ns & Ns & $*$ \\
\hline $\mathrm{C} 16: 0$ & $* * *$ & $* * *$ & Ns & $* * *$ \\
\hline $\mathrm{C} 17: 0$ & $* * *$ & $* * *$ & Ns & $*$ \\
\hline C17:1 & $* * *$ & $* * *$ & $* * *$ & Ns \\
\hline C18:0 & $* * *$ & $* *$ & Ns & $* * *$ \\
\hline C20:0 & $* * *$ & $* * *$ & * & $* * *$ \\
\hline $\mathrm{C} 22: 0$ & $* * *$ & $* *$ & $* * *$ & $* * *$ \\
\hline $\mathrm{C} 24: 0$ & $* * *$ & Ns & Ns & Ns \\
\hline $\mathrm{C} 16: 1$ & $* * *$ & $* *$ & $* * *$ & $* *$ \\
\hline C18:1 & $* * *$ & $* * *$ & $* * *$ & $* * *$ \\
\hline C18:2 & $* * *$ & $* * *$ & $* * *$ & $* * *$ \\
\hline $\mathrm{C} 18: 3$ & $* * *$ & $* * *$ & $* * *$ & $* * *$ \\
\hline C20:1 & $* * *$ & $* * *$ & $* *$ & $*$ \\
\hline$\sum \mathrm{SFA}$ & $* * *$ & $* * *$ & Ns & $* * *$ \\
\hline MUFA & $* * *$ & $* * *$ & $* * *$ & $* * *$ \\
\hline PUFA & $* * *$ & $* * *$ & $* * *$ & $* * *$ \\
\hline USFA & $* * *$ & $* *$ & $* * *$ & $* * *$ \\
\hline MUFA/PUFA & $* * *$ & $* * *$ & $* * *$ & $* * *$ \\
\hline C18:1/C18:2 & $* * *$ & $* * *$ & $* * *$ & $* * *$ \\
\hline Total & $* * *$ & Ns & $* * *$ & $* * *$ \\
\hline
\end{tabular}

***,** and * significant at $P<0.001,0.01$ or 0.05 , respectively.Ns $=$ not significant $(P>0.05)$. highest. These minimum and maximum values were found for genotypes within PDO Terra Fria. The second year of this study showed that samples from within this PDO had the highest values of all three PDO.

Chestnuts samples analyzed contained $17 \%$ saturated fatty acids (SFA), 83\% unsaturated fatty acids (USFA) consisting of $31 \%$ monounsaturated fatty acids (MUFA) and $52 \%$ of polyunsaturated fatty acids (PUFA) (Fig. 2). The proportions of USFA are similar to those reported by Ferreira-Cardoso (2002), Senter et al. (1994) and Desmaison and Adrian (1986) with reported USFA of $80.5 \%, 83 \%$ and $75 \%$, respectively.

The results presented in Tables 4 and 5 show that chestnut crude fat consists primarily of three FAs: linoleic, oleic and palmitic. These accounted for more than $85 \%$ of the total FA content, slightly higher than the $85 \%$ reported by Desmaison and Adrian (1986).

The effect of cultivar and locations (PDO) on total SFA content was statistically significant as shown in Table 3 . The cv. Aveleira had the lowest content $(14.08 \mathrm{~g} / 100 \mathrm{~g})$ in 2001 and cv. Carreiró (PDO Soutos da Lapa) in 2002 the highest content (18.64 g/100 g) (Table 4). The PDO Padrela had the lowest value $(15.45 \mathrm{~g} / 100 \mathrm{~g})$, and PDO Soutos da Lapa $(16.91 \mathrm{~g} / 100 \mathrm{~g})$ the highest value in the same year (Table 6). These values did not change significantly with harvest years. The SFA give the fat more stability, but they are considered harmful to the heart and blood vessels, so with respect to the SFA content, the cv. Aveleira is potentially the most beneficial to the human diet because it had the lowest SFA value.

The most important SFA was palmitic acid, with values between 12.54 and $16.80 \mathrm{~g} / 100 \mathrm{~g}$ for cv. Aveleira in 2001 and cv. Carreiró in 2002, respectively (Table 4). These values were consistently higher than the levels for the other saturated acids, which had relatively low values. These results are in agreement with those reported by Desmaison and Adrian (1986) and Künsch et al. (1999) for five Swiss cultivars and one Italian cultivar. Also, in other important crops in Mediterranean countries, such as olives, palmitic acid was the predominant SFA (Aguilera et al., 2005). Palmitic acid has been recognized as a major contributor to the build-up of serum cholesterol (Groff et al., 1996).

Concerning the total of MUFA, this varied significantly with cultivars, PDO and year (Table 3). The cv. Cota (PDO Padrela) had the lowest MUFA value $(22.46 \mathrm{~g} / 100 \mathrm{~g})$ in 2001, and cv. Trigueira (PDO Terra Fria) the highest value $(39.29 \mathrm{~g} / 100 \mathrm{~g})$ in 2002 (Table 5). The major MUFA in all genotypes tested was oleic acid, with ranges from $20.66 \mathrm{~g} /$ $100 \mathrm{~g}$ for cv. Cota in 2001 to $37.60 \mathrm{~g} / 100 \mathrm{~g}$ for cv. Trigueira in the 2002. The MUFA also varied significantly with locations: the PDO Padrela had the lowest MUFA value $(25.94 \mathrm{~g} / 100 \mathrm{~g})$ while PDO Terra Fria had the highest $(35.13 \mathrm{~g} / 100 \mathrm{~g})$ (Table 6). Recently it has been reported that MUFA were as effective as PUFA in the reduction of lowdensity-lipoprotein cholesterol in humans (Mensink and Katan, 1989). 


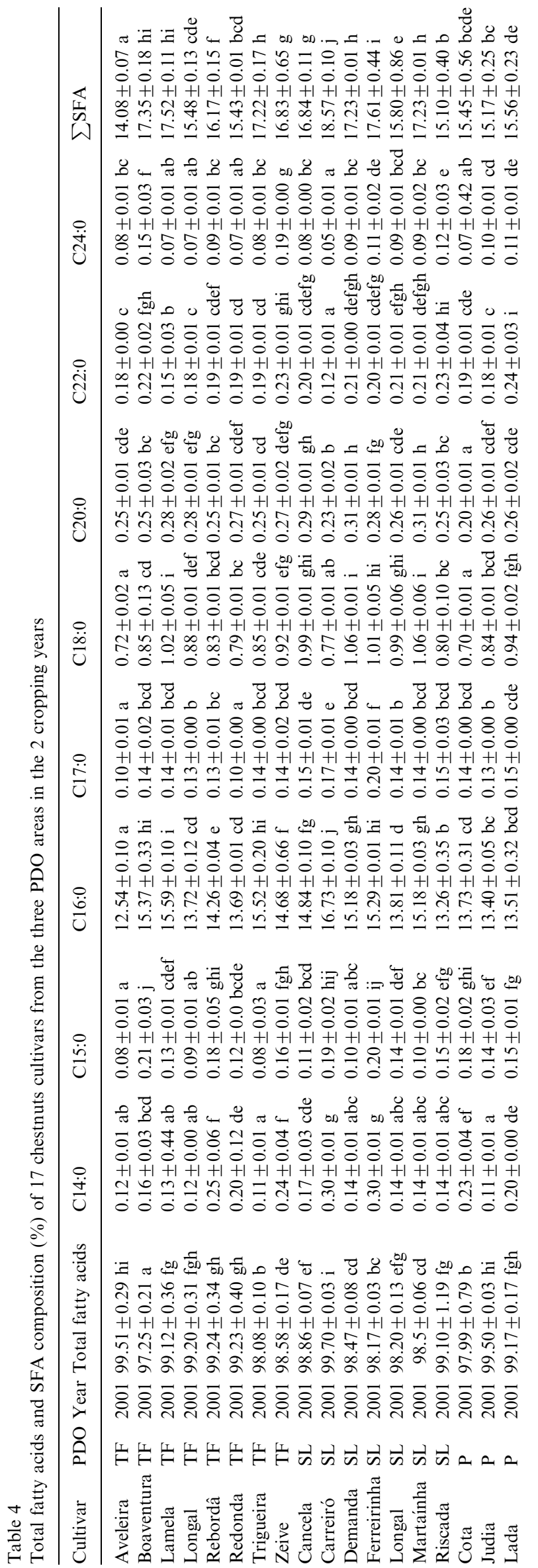

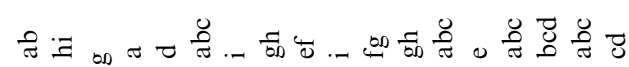

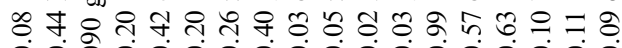

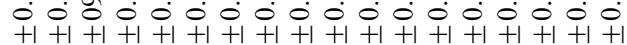

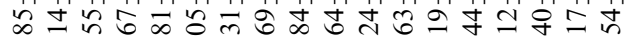

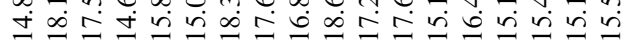
ช 0 0 สิ

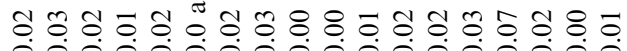
$+1+1+1+1+1+1+1+1+1+1+1+1+1+1+1+1+1+1$ $\exists \pm \infty \delta=5 \delta 2 \infty n \approx=25 m 501$

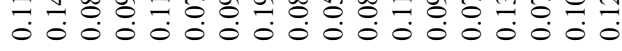

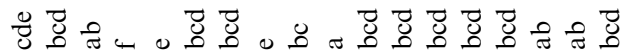

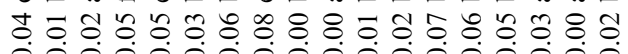

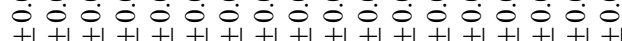
స̃ป ते :

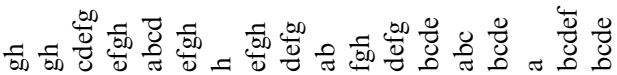

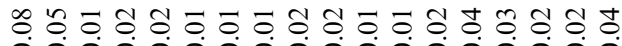

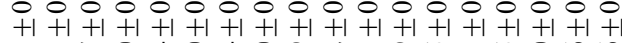
m 000000000000000000

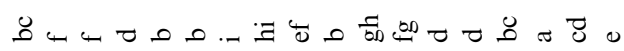
के है

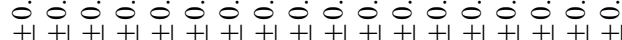

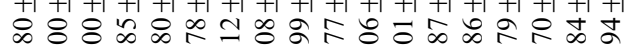

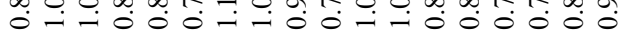

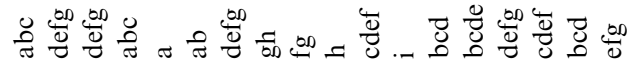

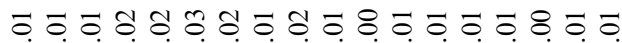

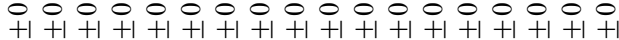
느늘

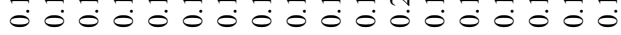

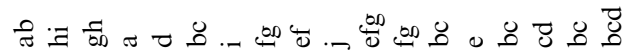
$\infty$ ले

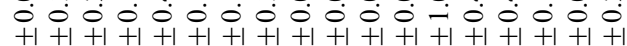

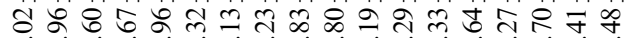

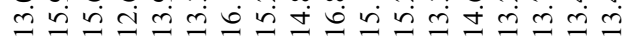

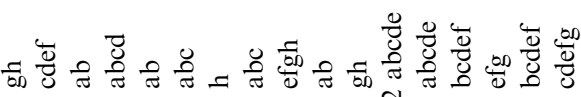

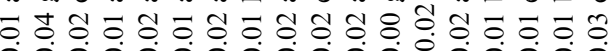
$+1+1+1+1+1+1+1+1+1+1+1+1+1+1+1+1+1+1$

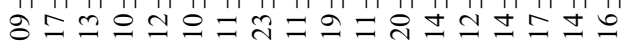

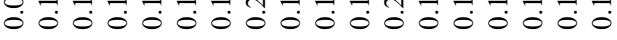

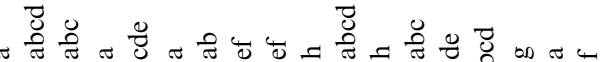

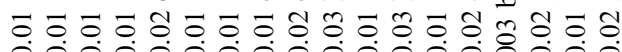

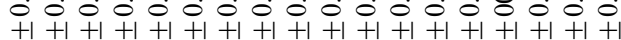

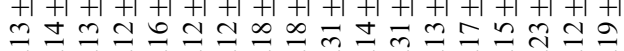
000000000000000000

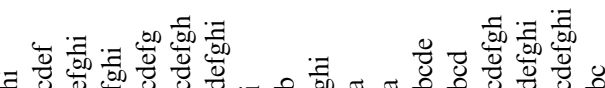

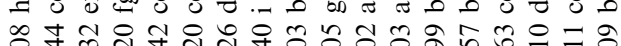

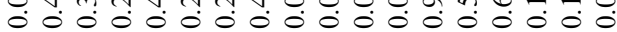
$+1+1+1+1+1+1+1+1+1+1+1+1+1+1+1+1+1+1$

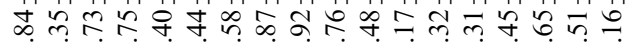
ลंส

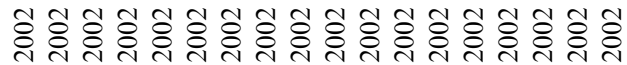

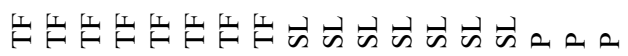

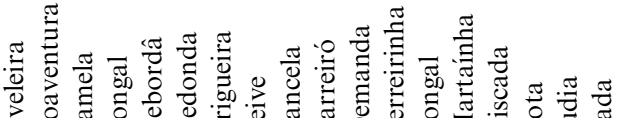




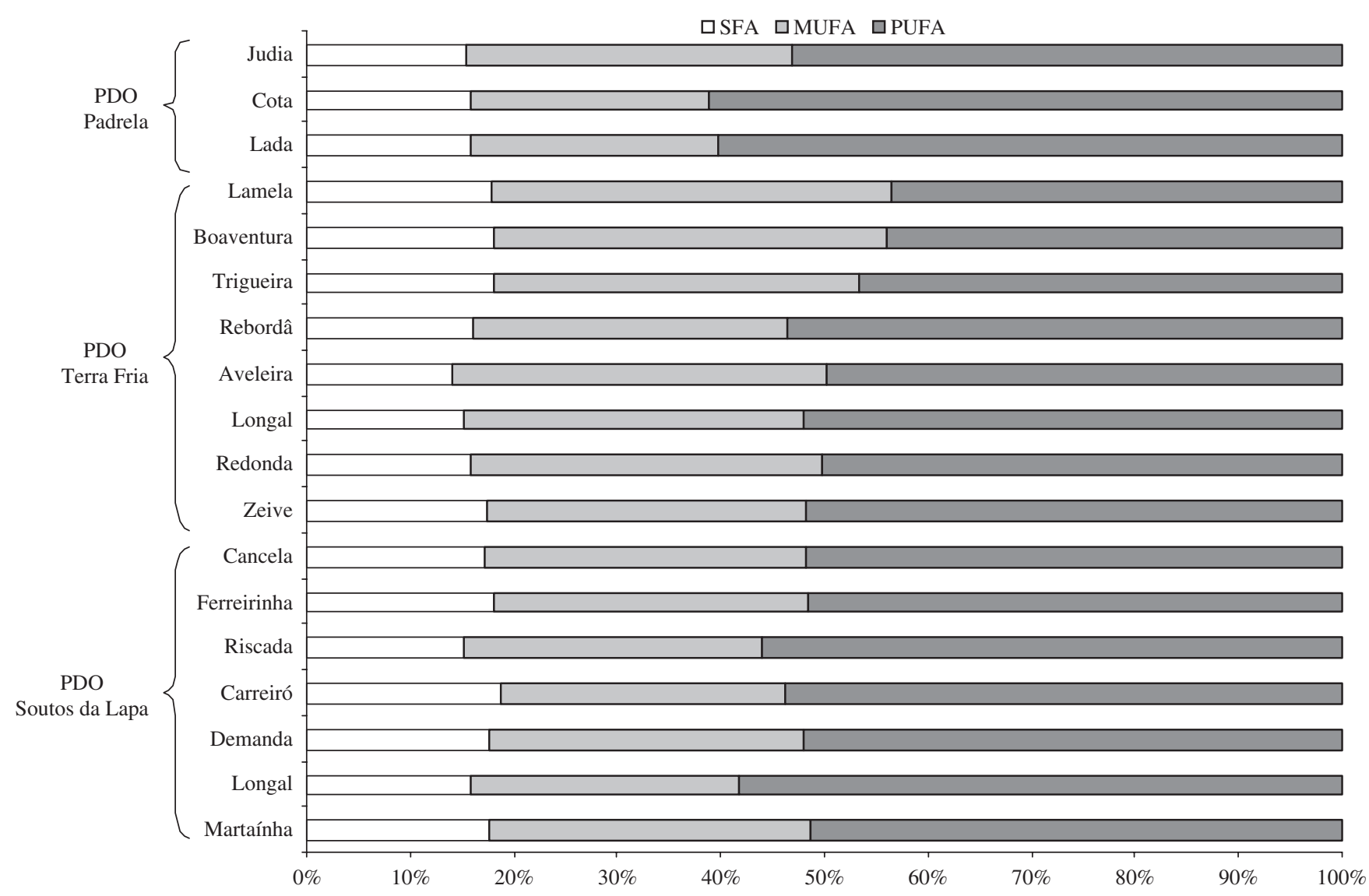

Fig. 2. Portuguese chestnuts: proportion of saturated (SFA), monounsaturated (MUFA) and polyunsaturated (PUFA) fatty acids.

The total PUFA content varied significantly with cultivars, PDO and year (Table 3). The cv. Trigueira had the lowest PUFA value $(41.98 \mathrm{~g} / 100 \mathrm{~g})$ in 2002 and cv. Cota the highest value $(60.11 \mathrm{~g} / 100 \mathrm{~g})$ in the same year (Table 5). Significant differences were found among PDO regions: Terra Fria had the lowest PUFA values $(48.02 \mathrm{~g} / 100 \mathrm{~g})$ while Padrela had the highest values $(57.61 \mathrm{~g} / 100 \mathrm{~g})$ in the same year (Table 6). Linoleic acid, the most important PUFA, had a value of $37.57 \mathrm{~g} / 100 \mathrm{~g}$ in cv. Trigueira in 2002 and $50.93 \mathrm{~g} / 100 \mathrm{~g}$ in cv. Lada in the same year (Table 5). Also, in other nut crops such as hazelnut and almond, the most important PUFA is linoleic acid, with values between $5.7 \mathrm{~g} / 100 \mathrm{~g}$ and $22.2 \mathrm{~g} / 100 \mathrm{~g}$ in hazelnuts (Abdallah et al., 1998 ) and between $15.4 \mathrm{~g} / 100 \mathrm{~g}$ and $22.2 \mathrm{~g} / 100 \mathrm{~g}$ in almonds (Parcerisa et al., 1993). It is generally accepted that the most important FA in chestnut fruit is linoleic acid (Ferreira-Cardoso, 2002; Desmaison and Adrian, 1986; Künsch et al., 1999; Senter et al., 1994) which, being an essential FA, has clear effects on human health. Consumers are especially interested in essential FAs, with emphasis on the health potential of PUFA. It is considered that these FAs play a natural preventive role in cardiovascular disease (Melgarejo and Artes, 2000). From these studies two potential health-promoting cultivars were identified: cv. Lada, with higher linoleic acid, and cv. Aveleira, with more USFA. With respect to the PDO areas, the Padrela consistently had the highest values of linoleic acid and USFA.

The ratio value of MUFA to PUFA was less than 1, which means a predominance of PUFA, in contrast to almond which presents low PUFA and high MUFA (Abdallah et al., 1998). This ratio varied significantly $(P<0.001)$ among genotypes, years and production regions (Table 3), with the minimum ratio value being 0.37 for $\mathrm{cv}$. Cota in 2001 and the maximum value of 0.94 in cv. Trigueira in 2002 (Table 7). With respect to the locations, the average values for the ratio was within the range 0.45-0.46 for PDO Padrela, 0.53-0.57 for PDO Soutos da Lapa and 0.69-0.74 for PDO Terra Fria in the years 2001 and 2002, respectively (Table 6).

Like the MUFA:PUFA ratio, the oleic:linoleic ratio was very low with significant differences among cultivar, PDO and year (Table 3). This ratio was lowest for cv. Cota (0.41) in 2001 and highest for cv. Trigueira (1.00) in 2002 (Table 7). The samples from PDO Padrela had the lowest average value $(0.50)$ and Terra Fria the highest $(0.80)$ (Table 6).

Thus the pool of oleic acid appears to be controlled by its conversion to linoleic, probably as a result of the enzymatic activity of oleic desaturase. According to Garcia et al. (1992) this enzyme controls the variation in FA composition in pistachio. 


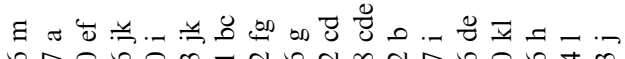
\& ㅇำ ㅇำ $\ll \quad 0 \quad 0 \quad 0 \quad 00000$

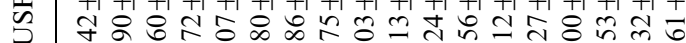
W

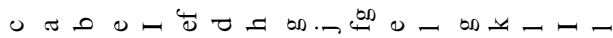
ปे $\varangle \quad \begin{aligned} & 0 \\ & 0\end{aligned}$

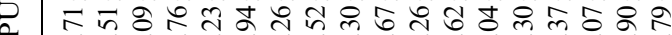
屯 రค

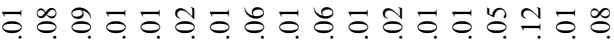

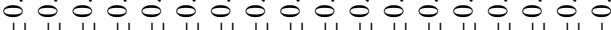
mon

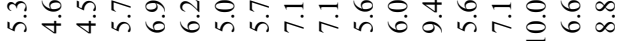

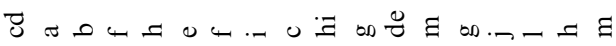
ช

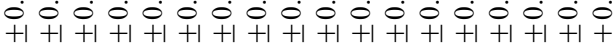

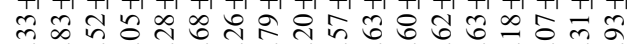

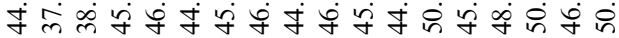

$\because$ $\because$. ำ $+1+1+1+1+1+1+1+1+1+1+1+1+1+1+1+1+1$ ₹六

. -

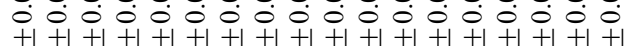

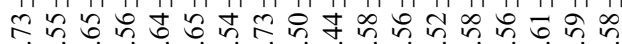
000000000000000000

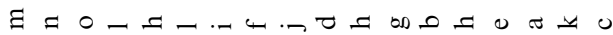

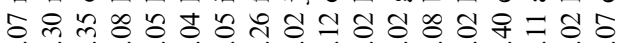

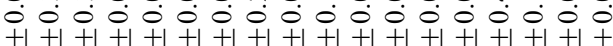

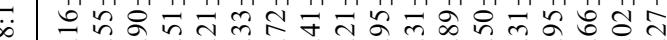

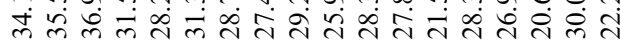

Ч

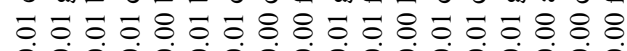

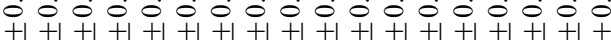

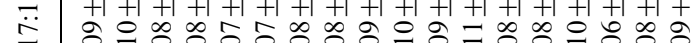

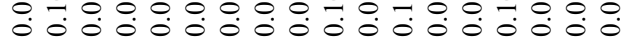

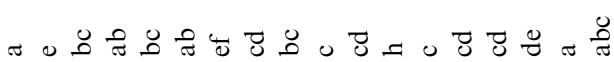

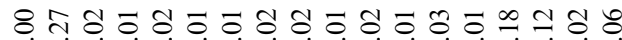

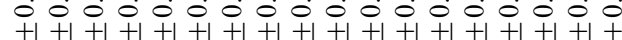
으

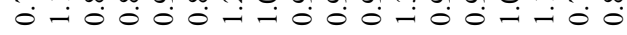

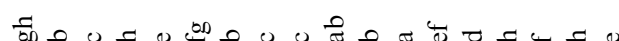

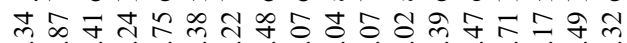
0000000 \& तิ

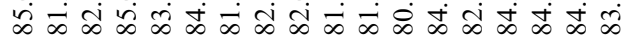

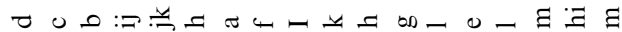

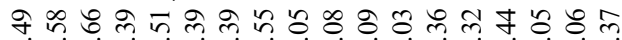
0000000000000000

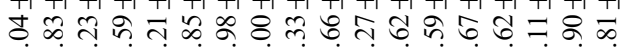

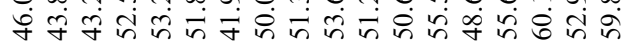

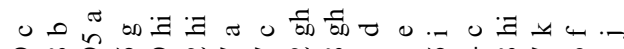

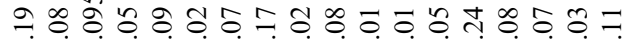
00000000000000000 $+1+1+1+1+1+1+1+1+1+1+1+1+1+1+1+1+1+1$

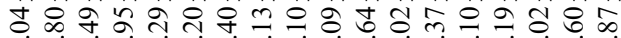

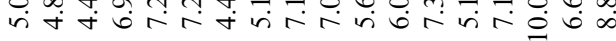

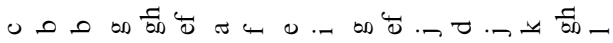

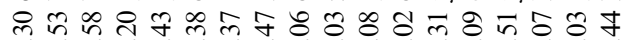

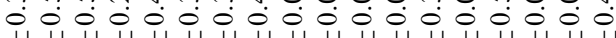

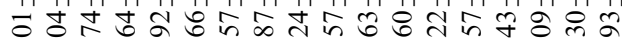

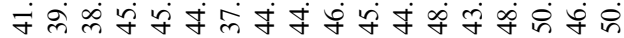

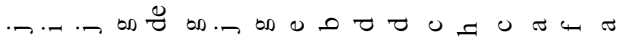
귀 ते

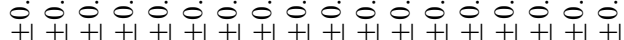
బূn

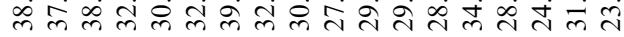

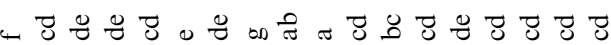
उ

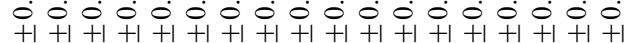

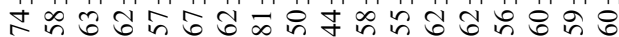
000000000000000000

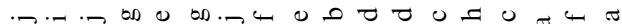
I $\infty$ m

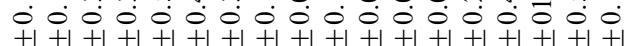
의

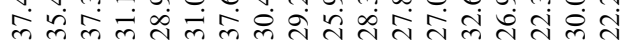

क्.

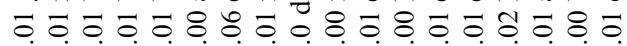
$+1+1+1+1+1+1+1+1+1+1+1+1+1+1+1+1+1+1$

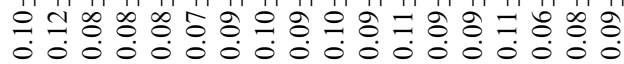

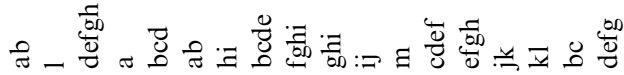
긍응 \&

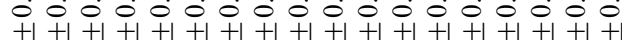

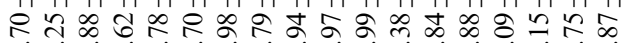
$0-000000000-004-00$

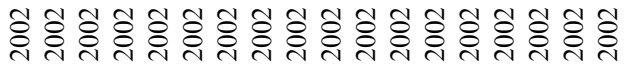

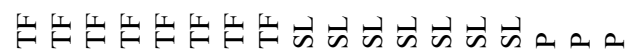

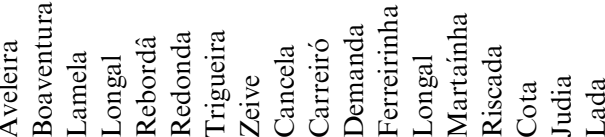


Table 6

SFA, USFA, MUFA, PUFA, ratios MUFA to PUFA and C18:1 (oleic acid) to C18:2 (linoleic acid) and crude fat content, of the three PDO areas on 2 years $(n=3 ;$ mean $\pm \mathrm{SD})$

\begin{tabular}{|c|c|c|c|c|c|c|c|c|}
\hline PDO & Year & SFA & USFA & MUFA & PUFA & MUFA/PUFA & $\mathrm{C} 18: 1 / \mathrm{C} 18: 2$ & Crude fat $(\% \mathrm{DM})$ \\
\hline SL & 2001 & $17.14 \pm 1.19 \mathrm{~b}$ & $81.79 \pm 1.35 \mathrm{a}$ & $28.11 \pm 2.45 \mathrm{a}$ & $53.68 \pm 3.14 \mathrm{~b}$ & $0.53 \pm 0.07 \mathrm{a}$ & $0.57 \pm 0.07 \mathrm{a}$ & $2.52 \pm 0.70 \mathrm{a}$ \\
\hline $\mathrm{TF}$ & 2002 & $16.56 \pm 1.54 \mathrm{~b}$ & $83.15 \pm 3.92 \mathrm{a}$ & $35.13 \pm 3.55 \mathrm{c}$ & $48.02 \pm 4.58 \mathrm{a}$ & $0.74 \pm 0.13 \mathrm{c}$ & $0.80 \pm 0.13 \mathrm{c}$ & $2.38 \pm 0.12 \mathrm{a}$ \\
\hline SL & 2002 & $16.91 \pm 1.19 \mathrm{~b}$ & $82.21 \pm 1.45 \mathrm{a}$ & $29.84 \pm 2.08 \mathrm{~b}$ & $52.37 \pm 2.55 \mathrm{~b}$ & $0.57 \pm 0.07 \mathrm{~b}$ & $0.62 \pm 0.69 \mathrm{~b}$ & $2.36 \pm 0.08 \mathrm{a}$ \\
\hline$P$ & 2002 & $15.45 \pm 0.19 \mathrm{a}$ & $83.55 \pm 0.95 \mathrm{a}$ & $25.94 \pm 4.36 \mathrm{a}$ & $57.61 \pm 3.54 \mathrm{c}$ & $0.46 \pm 0.11 \mathrm{a}$ & $0.50 \pm 0.12 \mathrm{a}$ & $2.50 \pm 0.17 \mathrm{a}$ \\
\hline
\end{tabular}

MUFA = monounsaturated fatty acids; PUFA = polyunsaturated fatty acids; SFA = saturated fatty acids; USFA = unsaturated fatty acids.

Different letters within one column denote statistically significant differences $(P<0.05)$ by ANOVA and Fisher's LSD test.

Table 7

Ratios MUFA to PUFA and C18:1 to C18:2

\begin{tabular}{|c|c|c|c|c|}
\hline Cultivar & PDO & Year & MUFA/PUFA & C18:1/C18:2 \\
\hline Aveleira & $\mathrm{TF}$ & 2001 & $0.72 \pm 0.00 \mathrm{i}$ & $0.77 \pm 0.021$ \\
\hline Boaventura & $\mathrm{TF}$ & 2001 & $0.88 \pm 0.01 \mathrm{j}$ & $0.94 \pm 0.01 \mathrm{~m}$ \\
\hline Lamela & $\mathrm{TF}$ & 2001 & $0.89 \pm 0.02 \mathrm{k}$ & $0.96 \pm 0.02 \mathrm{n}$ \\
\hline Longal & $\mathrm{TF}$ & 2001 & $0.65 \pm 0.00 \mathrm{~h}$ & $0.70 \pm 0.00 \mathrm{k}$ \\
\hline Rebordâ & $\mathrm{TF}$ & 2001 & $0.56 \pm 0.00 \mathrm{~d}$ & $0.61 \pm 0.00 \mathrm{~h}$ \\
\hline Redonda & $\mathrm{TF}$ & 2001 & $0.65 \pm 0.00 \mathrm{~h}$ & $0.70 \pm 0.00 \mathrm{k}$ \\
\hline Trigueira & TF & 2001 & $0.61 \pm 0.00 \mathrm{~g}$ & $0.63 \pm 0.00 \mathrm{~h}$ \\
\hline Zeive & $\mathrm{TF}$ & 2001 & $0.56 \pm 0.00 \mathrm{~d}$ & $0.59 \pm 0.00 \mathrm{e}$ \\
\hline Cancela & SL & 2001 & $0.60 \pm 0.00 \mathrm{fg}$ & $0.66 \pm 0.00 \mathrm{j}$ \\
\hline Carreiró & SL & 2001 & $0.51 \pm 0.00 \mathrm{c}$ & $0.56 \pm 0.00 \mathrm{~d}$ \\
\hline Demanda & SL & 2001 & $0.58 \pm 0.00 \mathrm{f}$ & $0.62 \pm 0.00 \mathrm{~g}$ \\
\hline Ferreirinha & SL & 2001 & $0.59 \pm 0.00$ ef & $0.63 \pm 0.00 \mathrm{gh}$ \\
\hline Longal & SL & 2001 & $0.38 \pm 0.00 \mathrm{a}$ & $0.42 \pm 0.00 \mathrm{~b}$ \\
\hline Martaínha & SL & 2001 & $0.58 \pm 0.00 \mathrm{e}$ & $0.62 \pm 0.00 \mathrm{~g}$ \\
\hline Riscada & SL & 2001 & $0.52 \pm 0.01 \mathrm{c}$ & $0.56 \pm 0.01 \mathrm{~d}$ \\
\hline Cota & $\mathrm{P}$ & 2001 & $0.37 \pm 0.00 \mathrm{a}$ & $0.41 \pm 0.00 \mathrm{a}$ \\
\hline Judia & $\mathrm{P}$ & 2001 & $0.59 \pm 0.02 \mathrm{ef}$ & $0.65 \pm 0.00 \mathrm{I}$ \\
\hline Lada & $\mathrm{P}$ & 2001 & $0.40 \pm 0.00 \mathrm{~b}$ & $0.44 \pm 0.00 \mathrm{c}$ \\
\hline Aveleira & $\mathrm{TF}$ & 2002 & $0.85 \pm 0.01 \mathrm{~h}$ & $0.91 \pm 0.01 \mathrm{~h}$ \\
\hline Boaventura & $\mathrm{TF}$ & 2002 & $0.85 \pm 0.01 \mathrm{~h}$ & $0.91 \pm 0.01 \mathrm{~h}$ \\
\hline Lamela & $\mathrm{TF}$ & 2002 & $0.90 \pm 0.02 \mathrm{i}$ & $0.97 \pm 0.02 \mathrm{i}$ \\
\hline Longal & $\mathrm{TF}$ & 2002 & $0.62 \pm 0.01 \mathrm{def}$ & $0.68 \pm 0.01$ ef \\
\hline Rebordâ & $\mathrm{TF}$ & 2002 & $0.57 \pm 0.01 \mathrm{c}$ & $0.63 \pm 0.01 \mathrm{~cd}$ \\
\hline Redonda & $\mathrm{TF}$ & 2002 & $0.63 \pm 0.01 \mathrm{ef}$ & $0.70 \pm 0.02 \mathrm{fg}$ \\
\hline Trigueira & $\mathrm{TF}$ & 2002 & $0.94 \pm 0.02 \mathrm{i}$ & $1.00 \pm 0.02 \mathrm{i}$ \\
\hline Zeive & $\mathrm{TF}$ & 2002 & $0.64 \pm 0.01 \mathrm{f}$ & $0.68 \pm 0.01 \mathrm{ef}$ \\
\hline Cancela & SL & 2002 & $0.60 \pm 0.00 \mathrm{cde}$ & $0.66 \pm 0.00 \mathrm{de}$ \\
\hline Carreiró & SL & 2002 & $0.51 \pm 0.00 \mathrm{~b}$ & $0.56 \pm 0.00 \mathrm{~b}$ \\
\hline Demanda & SL & 2002 & $0.58 \pm 0.00 \mathrm{c}$ & $0.62 \pm 0.00 \mathrm{c}$ \\
\hline Ferreirinha & SL & 2002 & $0.59 \pm 0.00 \mathrm{~cd}$ & $0.63 \pm 0.00 \mathrm{~cd}$ \\
\hline Longal & SL & 2002 & $0.51 \pm 0.01 \mathrm{~b}$ & $0.56 \pm 0.00 \mathrm{~b}$ \\
\hline Martaínha & SL & 2002 & $0.68 \pm 0.01 \mathrm{~g}$ & $0.72 \pm 0.01 \mathrm{~g}$ \\
\hline Riscada & SL & 2002 & $0.52 \pm 0.01 \mathrm{~b}$ & $0.56 \pm 0.01 \mathrm{~b}$ \\
\hline Cota & $\mathrm{P}$ & 2002 & $0.40 \pm 0.00 \mathrm{a}$ & $0.45 \pm 0.00 \mathrm{a}$ \\
\hline Judia & $\mathrm{P}$ & 2002 & $0.59 \pm 0.01 \mathrm{~cd}$ & $0.65 \pm 0.01 \mathrm{cde}$ \\
\hline Lada & $\mathrm{P}$ & 2002 & $0.38 \pm 0.01 \mathrm{a}$ & $0.44 \pm 0.01 \mathrm{a}$ \\
\hline
\end{tabular}

MUFA = monounsaturated fatty acids; PUFA = polyunsaturated fatty acids.

Different letters within one column denote statistically significant differences $(P<0.05)$ by ANOVA and Fisher's LSD test.

Values are average of three individual samples each analysed in triplicate \pm standard deviation.

In addition, a statistical regression study was performed between the parameters of oleic, linoleic and linolenic acid levels. The statistical results for correlation coefficient $\left(R^{2}\right)$ and significant level $(P)$ are shown in Fig. 3. There is a positive correlation between linoleic and linolenic FAs content $\left(R^{2}=0.54, \quad P<0.0001\right)$. On other hand, the 

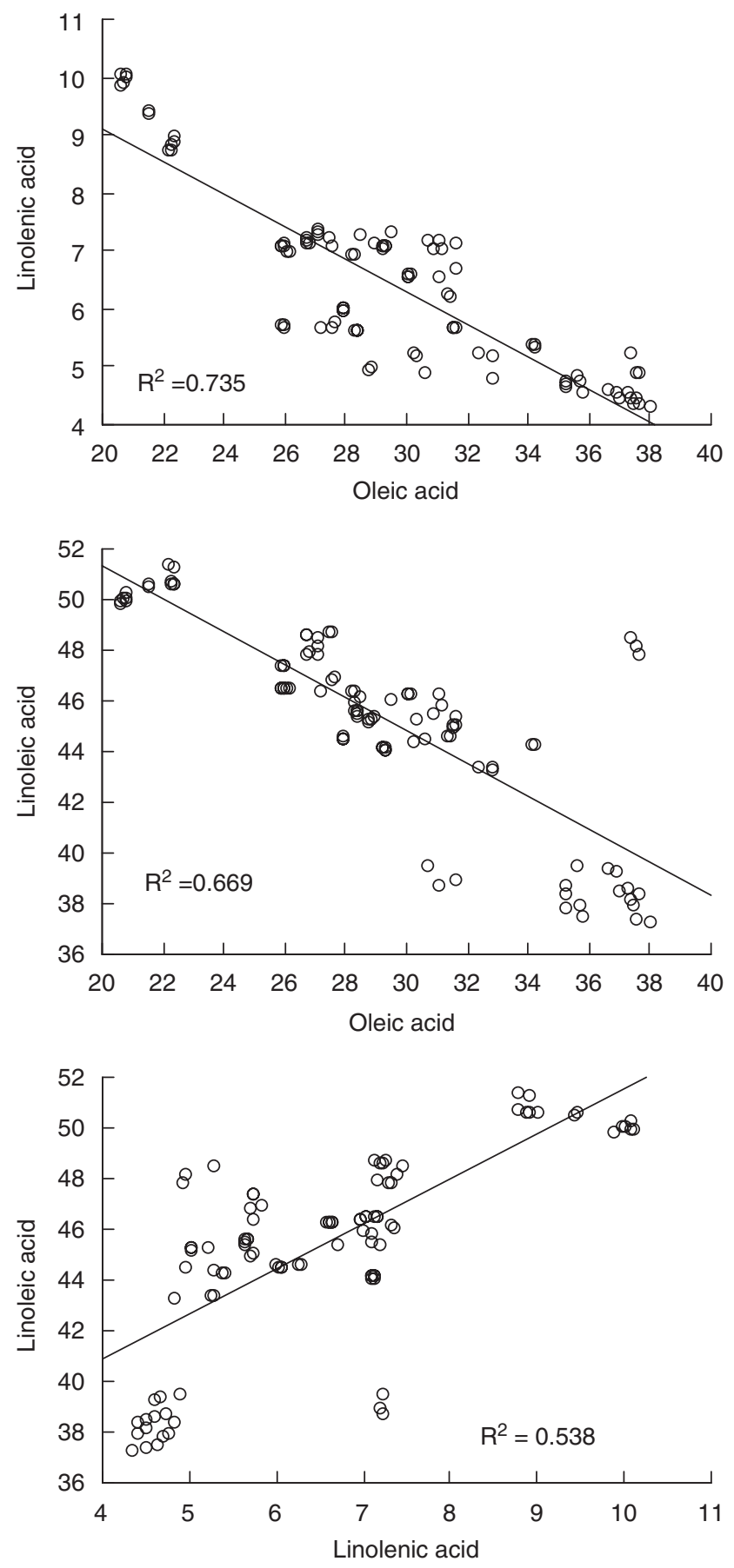

Fig. 3. Portuguese chestnuts: relationship between linolenic and linoleic, oleic and linoleic and between oleic and linolenic, all samples, both years. correlation between oleic and linoleic $\left(R^{2}=0.74\right.$, $P<0.0001)$ and between oleic and linolenic $\left(R^{2}=0.67\right.$, $P<0.0001)$ are negative, these correlations are in agreement with previous observations by Garcia et al. (1992, 1994) for pistachio and hazelnut, and by Abdallah et al. (1998) for almond.

The analysis of variance for cv. Longal, the only traditional cv. growing in the PDO Soutos da Lapa and PDO Terra Fria (Table 8) showed significant differences for PDO, year and the interaction PDO $\times$ year for MUFA and PUFA values, and for the ratios of MUFA:PUFA and oleic:linoleic. The SFA values were significantly dependent for location, where Terra Fria had the lowest value $(14.67 \mathrm{~g} / 100 \mathrm{~g})$ in 2002 (Table 4) and the highest value for USFA $(85.09 \mathrm{~g} / 100 \mathrm{~g})$ (Table 5) in the same year.

The values of MUFA had ranges between $23.08 \mathrm{~g} / 100 \mathrm{~g}$ in PDO Soutos da Lapa and $32.96 \mathrm{~g} / 100 \mathrm{~g}$ in PDO Terra Fria. As expected, the lowest average value for PUFA was found in samples from PDO Terra Fria $(50.76 \mathrm{~g} / 100 \mathrm{~g})$ and the highest in samples from Soutos da Lapa $(60.04 \mathrm{~g} / 100 \mathrm{~g})$. The ratio of MUFA to PUFA was higher in Terra Fria than in Soutos da Lapa and the ratio of oleic to linoleic showed the same behavior (Table 7). The crude fat content was significantly dependent on location and the interaction PDO $\times$ year, varying between $1.97 \mathrm{~g} / 100 \mathrm{~g}$ in Soutos da Lapa in 2001 and $2.53 \mathrm{~g} / 100 \mathrm{~g}$ in PDO Terra Fria in the same year.

For this cultivar, the PDO with consistently better nutritional qualities for chestnuts, like low SFA and high USFA, is PDO Terra Fria. The cv. Longal is not traditionally grown in PDO Padrela. The soil genesis is very different among these two regions: Soutos da Lapa has granite soils whereas Terra Fria has schist soils (Table 1). Also Gomes et al. (1997) detected a relationship between protein content of chestnuts and the type of soil in which they had grown. Chestnuts from places in which schists are predominant showed much higher protein content than those from granite-based soils.

\section{Conclusions}

The cultivars studied confirm that chestnuts contain low crude fat, low SFA and high unsaturated fatty acid. The major FAs are linoleic, oleic and palmitic and these accounted for more than $85 \%$ of the total FA content.

Table 8

Analysis of variance for cv. Longal to SFA, USFA, MUFAs, PUFAs, ratios of MUFA to PUFA and C18:1 to C18:2 and crude fat content

\begin{tabular}{llllllll}
\hline & SFAs & USFA & MUFAs & PUFAs & MUFA/PUFA & C18:1/C18:2 & Crude fat (\%) \\
\hline PDO & $*$ & $* * *$ & $* * *$ & $* * *$ & $* * *$ & $* * *$ & $* * *$ \\
Year & Ns & $* * *$ & $* * *$ & $* * *$ & $* * *$ & Ns \\
PDO $\times$ year & Ns & Ns & $* * *$ & $* * *$ & $* * *$ & $* * *$ & $* *$ \\
\hline
\end{tabular}

MUFA = monounsaturated fatty acids; PUFA = polyunsaturated fatty acids; SFA = saturated fatty acids; USFA = unsaturated fatty acids. 
From these results, two cultivars were identified that could be promoted to consumers based on their increased potential health effects: cv. Lada with consistently high linoleic acid content, and cv. Aveleira that has a higher proportion of USFA. With respect to the individual PDO regions, PDO Padrela consistently produced chestnuts with these health-beneficial properties such as the highest content of linoleic acid. The variation detected among cultivars and PDO areas may reflect differences in genotype and is clearly influenced by environmental and growing conditions.

The Longal chestnuts, the only traditional cv. growing on two different PDO areas, had higher nutritional qualities in PDO Terra Fria, which further confirms that the ecological conditions where chestnut orchards are established influence the subsequent qualities of the chestnuts.

\section{Acknowledgement}

The authors wish to thank Dr. Richard Bennett (UTAD) for critically reviewing the versions of the manuscript.

\section{References}

Abdallah, A., Ahumada, M.H., Gradziel, T.M., 1998. Oil content and fatty acid composition of almond kernels from different genotypes and California production regions. Journal of American Society and Horticulture 123, 1029-1033.

Aguilera, M.P., Beltrán, G., Ortega, D., Fernández, A., Jiménez, A., Uceda, M., 2005. Characterisation of virgin olive oil of Italian olive cultivars:'Frantoio' and 'Leccino', grown in Andalusia. Food Chemistry $89,387-391$.

AOAC, 2000. Official Methods of Analysis of AOAC International, 17th Edition. Association of Official Analytical Chemists, USA.

Benatti, P., Peluso, G., Nicolai, R., Calvani, M., 2004. Polyunsaturated fatty acids: biochemical, nutritional and epigenetic properties. Journal of the American College of Nutrition 23 (4), 281-302.

Desmaison, A., Adrian, J., 1986. La place de la châtaigne en alimentation. Medicine et Nutrition 22 (3), 174-180.

European Union Comission, 1991. Regulation EEC 2568/91 on the characteristics of olive oil and olive pomace and their analytical methods. Official Journal of European Communities L428.

FAO, 1998. World reference base for soil resources. FAO, Rome.

Ferreira-Cardoso, J.V., 2002. Caracterização e valorização do fruto de Castanea sativa Mill. Composição química, valor nutritivo e efeito da sua utilização na engorda de porcos Duroc. Ph.D. Thesis, UTAD, Portugal.

Ferreira-Cardoso, J.V., Sequeira, C.A., Rodrigues, L., Gomes, E.F., 1999. Lipid composition of Castanea sativa Mill. fruits of some native portuguese cultivars. Acta Horticulturae 494, 133-138.
Garcia, J.M., Agar, I.T., Ve Streif, J., 1992. Fat content and fatty acid composition in individual seeds of pistachio varieties grown in Turkey. Gartenbauwissenschaft 57, 130-133.

Garcia, J.M., Agar, I.T., Ve Streif, J., 1994. Lipid characteristics of kernels from different hazelnut varieties. Turkish Journal of Agriculture and Forestry 18, 199-202.

Gomes, A.L., Abreu, C.G., Castro, L.T., 1997. COLUTAD um clone de castanheiro com resistência à doença da tinta. NATO/SFS Programme III PO-Chestnut. UTAD, Vila Real.

GPPAA, 2003. Anuário vegetal. Gabinete de planeamento e política agroalimentar. Ministério da Agricultura, Pescas e Florestas, 304pp.

Groff, J.L., Gropper, S.S., Hunt, S.M., 1996. Lipids. Advanced Nutrition and Human Metabolism 00, 113-146.

Hardman, E.W., 2002. Omega-3 fatty acids to augment cancer therapy. Journal of Nutrition 132, 3508S-3512S.

Hartman, L., Lago, R.C., 1973. Rapid preparation of fatty acid methyl esters from lipids. Laboratory Practices 22 (6), 475-476.

Kitta, K., Ebihara, M., Iizuka, T., Yoshikawa, R., Isshiki, K., Kawamoto, S., 2005. Variations in lipid content and fatty acid composition of major non-glutinous rice cultivars in Japan. Journal of Food Composition and Analysis 18, 269-278.

Künsch, U., Scharer, H., Conedera, M., Sassella, A., Jermini, M., Jelmini, G., 1999. Quality assessment of chestnut fruits. Acta Horticulturae 494, 119-127.

McCarthy, M.A., Meredith, F.I., 1988. Nutrient data on chestnuts consumed in the United States. Economy Botany 42, 29-36.

Melgarejo, P., Artes, F., 2000. Total lipid content and fatty acid composition of oil seed from lesser known sweet pomegranate clones. Journal of the Science of Food and Agriculture 80, 1452-1454.

Mensink, R.P., Katan, M.B., 1989. Effect of a diet enriched wit monounsaturated or polyunsaturated fatty acids on levels of lowdensity and high-density lipoprotein cholesterol in healthy women and men. New England Journal of Medicine 321, 436-441.

Parcerisa, J., Boatella, J., Codony, R., Farràn, A., Garcia, J., Lopez, A., Rafecas, M., Romero, A., 1993. Influence of variety and geographical origin on the lipid fraction of hazelnuts (Corylus avellana L.) from Spain: I. Fatty acid composition. Food Chemistry 48, 411-414.

Parcerisa, J., Rafecas, M., Castellote, A.I., Codony, R., Farràn, A., Garcia, J., Lopez, A., Romero, A., Boatella, J., 1994. Influence of variety and geographical origin on the lipid fraction of hazelnuts (Corylus avellana L.) from Spain: II. Triglyceride composition. Food Chemistry 50, 245-249.

Pazianas, M., Butcher, G.P., Subhani, J.M., Finch, P.J., Ang, L., Collins, C., Heaney, R.P., Zaidi, M., Maxwell, J.D., 2005. Calcium absorption and bone mineral density in celiacs after long term treatment with gluten-free diet and adequate calcium intake. Osteoporosis International 16, 56-63.

Senter, S.D., Payne, J.A., Miller, G., Anagnosakis, S.L., 1994. Comparison of total lipids, fatty acids sugars and non-volatile organic acids in nuts from four Castanea species. Journal of the Science of Food and Agriculture 65, 223-227.

Üstün, N., Tosun, Y., Serdar, U., 1999. Technological properties of chestnut varieties grown in Erfelek district of Sinopy city. Acta Horticulturae 494, 107-110. 